\title{
A Preliminary Study and Validation of Characters as the Basis for Merdeka Belajar Program in University Level
}

\author{
Miftakhul Jannah ${ }^{1}, *$ Aris Rudi Purnomo ${ }^{2}$, Prima Vidya Asteria ${ }^{3}$, Ricky Eka \\ Putra $^{4}$
}

1,2,3,4 Universitas Negeri Surabaya

"Corresponding author.Email: miftakhuljannah@unesa.ac.id

\begin{abstract}
This research aims at generating and validating items of characters relevant to Curriculum Merdeka Belajar. This research used focus group discussion and content validity ratio to determine the validity of the items. Fifty participants were involved to give their response in the questionnaire using g-form format. Results showed that there is a reduction over 32 items built from four different sources, namely, Unesa character Idaman Jelita, characters from the Ministry of Education and Culture of Indonesia, Pancasila student characters, and Student Rating Management System (Simkatmawa). It resulted in 21 items of characters which can be considered describing what students should have when they are in the Curriculum of Merdeka Belajar implementation. CVR score of less than 0.29 is rejected to be on the list of relevant characters.
\end{abstract}

Keywords: Merdeka Belajar Program, A Perliminary Study dan Validation of Character

\section{INTRODUCTION}

Character education is an integral part of the educational process that shapes the way individuals think and act responsibly [1]. In higher education, this ability directs the knowledge and skills possessed by students to become supporters in career development [1], in community relations [2], and skills in caring for the environment [3].

To realize the things above, the State University of Surabaya has three references that are used to build student character. The first is the character strengthening guidelines developed by the Ministry of Education and Culture which contain 18 character values. The second guideline is the character values listed in the Student Rating Management System (Simkatmawa) in 2020. This system supports the mental character of nationality which consists of eight character values. The last is the character value of Idaman Jelita which stands for faith, intelligent, independent, honest, caring, and tough [4]. In detail, the three guidelines show a wedge consisting of spiritual aspects, selfactualization, and defending the country.

In the era of society 5.0, these characters were tested, especially with the implementation of the Merdeka Learning Campus Merdeka (MBKM) program. According to Yamin and Syahrir [5], independence learns to test innovative characters, social sensitivity, and independence when students face real-world problems. Zulfa Izza and Susilawati [6] state that independent learning requires a tough and innovative attitude to complete tasks related to time management. For Unesa, the above characters have high urgency because Unesa produces graduate teacher candidates who can educate and transmit positive characters to students.
To find out how far the character growth of Unesa students is, several studies were carried out. Suyanto et al. [7] stated that Unesa students have a positive perspective on the diversity of religions, races, and opinions, especially for those who take roles in organizations. Others, [4] involving 48 Unesa students from 18 Study Programs found that in general they have an understanding that the values of national character originating from Pancasila can be learned from entrepreneurial activities.

Unfortunately, the results of this study are still partial and do not describe the characters associated with the three value guidelines used at Unesa. Research needs to develop characters that are representative and relevant to the MBKM curriculum and can show the characteristics of Unesa students. Therefore, through this article, several steps were taken to formulate these characters and test their initial validity.

\section{METHODS}

This research employed three steps to determine what characters need to be implanted in the educational system of Universitas Negeri Surabaya (Unesa). These include reviewing the literature or documents, generating items or values, and validating them in terms of the appropriateness to the implemented curriculum of Merdeka Belajar.

\subsection{Literature review and values generation}

In terms of generating items, the research started with checking the values of characters from four different sources, namely Unesa characters, characters from the Ministry of Education and Culture, Pancasila students' personalities, and characters from higher education. From these documents, the research extracted 32 values or items 
relevant to the expectation of curriculum Merdeka Belajar, in which students must be able to fulfill what they need autonomously and be responsible for what they have done [8].

The values or items were formatted in the google form and administered to 50 participants in the next stage. Those participants were chosen purposively by which they include head of units, head of departments, lecturers, and personnel of student organizations. It is considered that they play a crucial role in conducting policies and activities at the university level, especially those related to character building. The questionnaire was then rated on a two-point Likert Scale: (1) irrelevant and (2) relevant.

\subsection{Content validity of the values}

The research employed both quantitative and qualitative data analysis to make sure that the extracted values meet the requirements of the curriculum. It means that the index of agreement and the experts' judgement can help characterize the degree of relevancy of the items [9]. The quantitative analysis dealt with the formula of content validity ratio (CVR). In contrast, the qualitative one was done through a focus group discussion with two invited experts from the psychology faculty of two different institutions, Ma Chung University and Universitas Islam Negeri Sunan Ampel, Indonesia. The formula to calculate CVR is as follows.

CVR $=\frac{\left[n e-\left(_{2}\right) \stackrel{N}{N}\right.}{N / 2}($ Lawshe, 1975)

$n e=$ the number of participants who choose the value or item being relevant

$\mathrm{N}=$ total of participants involved in the survey

The calculation results were then compared to the Lawshe table (Zeraati \& Alavi, 2014). For qualitative analysis, the experts give suggestions towards the items based on their knowledge and experiences. The changing of the amount of the items was determined using these analyses.

\section{RESULTS AND DISCUSSION}

\subsection{Generating items or character values}

The character values collected are thirty-two values extracted from four sources, namely the Unesa Idaman Jelita character (Faith, Intelligent, Independent, Honest, Caring, and Tough), 18 characters from the Ministry of Education and Culture, Simkatmawa Character, and Pancasila Student Character. The thirty-two characters were chosen based on their completeness in shaping students' personalities who are ready to face conditions in which they are faced with the challenges of uncertainty. The characters and their definitions can be seen in table 3.1.

Table 3.1 Character Values and Definitions

\begin{tabular}{|c|c|c|}
\hline No. & Values & Definition \\
\hline 1 & Faith & $\begin{array}{l}\text { An attitude that shows the } \\
\text { ability to distinguish between }\end{array}$ \\
\hline
\end{tabular}

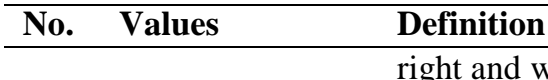

right and wrong in accordance

with the student's beliefs.

2 Intelligent

Attitudes that show the ability to understand certain concepts comprehensively and skillfully use them proportionally.

3 Independent An attitude that shows the ability to stand alone and not always depend on others.

$4 \quad$ Honest

5 Care

An attitude that shows the ability to say and act as it is. An attitude that shows the ability to pay attention and be involved in the circumstances and problems that exist in the surrounding environment.

6 Tough

7 Defend the Country

8 Tolerance

9 Discipline

10 Hard work

11 Creative

12 Democratic

13 Curious

14 Spirit of nationality

15 Appreciating

Achievements

16 Communicative
An attitude that shows the ability to survive in various circumstances.

An attitude that shows the ability to prioritize the interests of the nation and state based on Pancasila and the 1945 Constitution.

An attitude that shows the ability to respect each other's differences between fellow human beings.

Attitudes that show the ability to comply with applicable regulations.

An attitude that shows the ability to act seriously by using all the power possessed to achieve the target.

An attitude that shows the ability to solve problems with new and adaptive ideas.

An attitude that shows the ability to prioritize equal rights and obligations for the common good.

An attitude that shows the ability to find out information about a thing.

An attitude that shows the ability to build the nation according to their field of expertise and is proud to use domestically created products.

An attitude that shows the ability to recognize and appreciate the achievements of oneself and others.

Attitudes that show the ability to convey information effectively so that they can cooperate with others. 


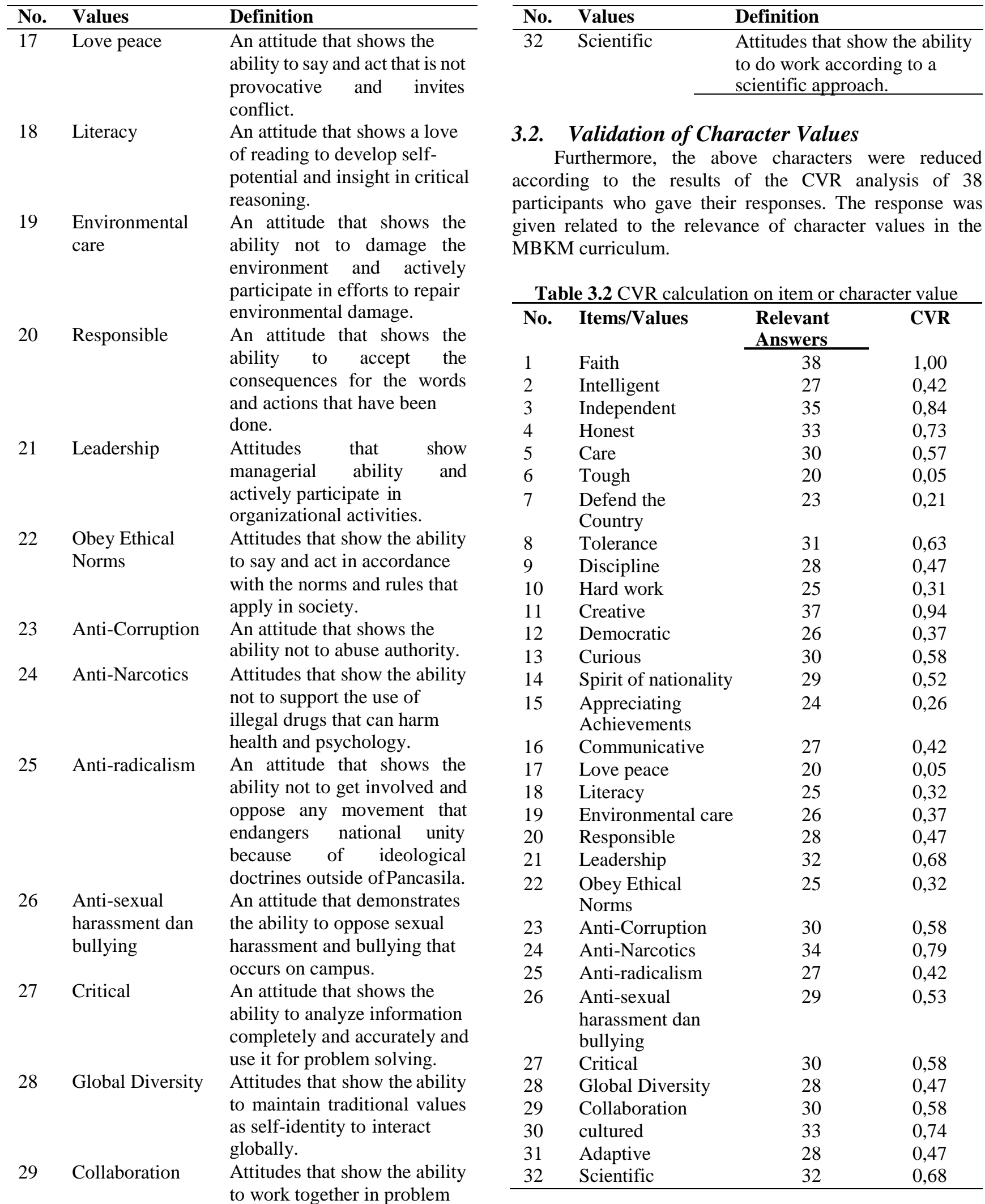

30 cultured An attitude that shows the ability to uphold and preserve the nation's culture.

31 Adaptive Attitudes that show the ability to easily adapt (self) to various circumstances.

Reduction of character items in table 3.2 is done if the CVR value is less than 0.29 . This value was obtained from the number of participants who answered relevant less than 25 people. Some of the reduced values include being tough, defending the country, working hard, appreciating achievements, and loving peace, so that the total character values are 27character values. These values are then discussed through focus group discussions (FGD). Some of the inputs from the FGD are presented in table 3.3. 
Table 3.3 Recommended FGD Results Character Values Unesa Mission Values

\begin{tabular}{l}
\hline Organizing learner-centred \\
education and learning by \\
using an effective learning \\
approach and optimizing \\
the use of technology. \\
Conducting research in \\
educational sciences, \\
natural sciences, socio- \\
cultural sciences, arts, \\
and/or sports, and the \\
development of \\
technology whose findings \\
are beneficial for the \\
development of science \\
and the welfare of society. \\
Disseminate science, \\
technology, arts, culture \\
and sports, as well as \\
research results through \\
community service \\
activities that are oriented \\
towards community \\
empowerment and culture. \\
Realizing Unesa as an \\
educational center, \\
especially primary and \\
secondary education as \\
well as a scientific center \\
based on the noble values \\
of national culture. \\
Organizing an \\
autonomous, accountable, \\
and transparent university \\
meeting that ensures \\
quality and continuous \\
quality improvement. \\
\hline
\end{tabular}

Independent and tough

citical thinking,

critical thinking, innovative and adaptive

caring, collaboration, and tolerance

initiative, capable, and love the homeland

honest, assertive, and responsible

Through FGDs, experts gave recommendations that character values should be in line with Unesa's mission. This is a step to strengthen the character of Unesa students. Regarding MBKM, Unesa's mission is considered sufficient to accommodate the needs in the curriculum. Continuity in developing student skills to develop science from a quality aspect shows that Unesa as an educational institution is able to adapt to curriculum developments.

Based on the results of the CVR and FGD analysis, it was decided that there was a reduction in character items from thirty-two to 21 characters. Consideration of the reduction is done by looking at the similarity of the character domain or the presence of the same slice. In addition, the twenty-one characters can be categorized into five competencies, namely Personality, Social, Literacy, Leadership, and Citizenship. According to table 3.4.

Table 3.4 Categorization of MBKM supporting character values

Items of characters

\begin{tabular}{ll}
\hline Personality & $\begin{array}{c}\text { Spiritual, responsible, honest, } \\
\text { independent, and assertive } \\
\text { Caring, adaptive, mutual } \\
\text { cooperation, obedient to ethical } \\
\text { norms, and communicative }\end{array}$ \\
Literacy & $\begin{array}{l}\text { Think critically, intelligently, } \\
\text { and scientifically } \\
\text { Capable, creative and innovative, } \\
\text { democratic, and initiative } \\
\text { Cove for the homeland, anti- } \\
\text { Citizenship }\end{array}$ \\
& $\begin{array}{l}\text { corruption, drugs, radicalism, } \\
\text { sexual harassment and bullying, } \\
\text { national spirit, global diversity, }\end{array}$
\end{tabular}

\section{CONCLUSION}

Based on the results of the study, there are thirty-two character values that can support Unesa students in learning activities in the MBKM Curriculum. These items were determined through CVR analysis with a minimum acceptance score of 0.29 . In addition, the reduction process was also carried out through FGDs, which saw that characters must be in line with Unesa's mission.

\section{REFERENCES}

[1] Christiana, W. (2005). Upaya Penerapan Pendidikan Karakter Bagi Mahasiswa (Studi Kasus di Jurusan Teknik Industri UK Petra). Jurnal Teknik Industri (Vol. 7, Issue 1). https://doi.org/10.9744/JTI.7.1.PP. 83-90

[2] Lawshe, C. H. (1975). A Quantitative Approach to Content Validity. Personnel Psychology, 28(4), 563575 . 6570.1975.tb01393.x

[3] Nurlaela, L. (2019). General Education Untuk Pengembangan Karakter Mahasiswa Di Era Revolusi Industri 4.0. September, 204-207.

[4] Polit, D. F., Beck, C. T., \& Owen, S. V. (2007). Is the CVI an acceptable indicator of content validity? Appraisal and recommendations. Research in Nursing \& Health, 30(4), 459-467. https://doi.org/10.1002/nur.20199

[5] Purwanti, D. (2017). Pendidikan karakter peduli lingkungan dan implementasinya. Dwija cendekia: Jurnal Riset Pedagogik, 1(2). https://doi.org/10.20961/jdc.v1i2.17622

[6] Susanti, S., Handayaningrum, W., \& Subroto, W. T. (2019). Student's Perception About Entrepreneurship Containing the Value of Pancasila as a Basic Construction of Entrepreneurship's Subject in Unesa. Dinamika Pendidikan, 14(1), 60-75. https://doi.org/10.15294/dp.v14i1.18134

[7] Susilawati, N. (2021). Merdeka Belajar dan Kampus Merdeka Dalam Pandangan Filsafat Pendidikan 
Humanisme. Jurnal Sikola: Jurnal Kajian Pendidikan Dan Pembelajaran, 2(3), 203-219. https://doi.org/10.24036/sikola.v2i3.108

[8] Suyanto, T., Pramono, M., \& Sari, D. A. P. (2019). Multicultural Leadership of Student Activists to Creating Democratic Campus. 335(ICESSHum), 292297. https://doi.org/10.2991/icesshum-19.2019.47

[9] Suyitno, I. (2012). Pengembangan Pendidikan Karakter dan Budaya Bangsa Berwawasan Kearifan Lokal. Jurnal Pendidikan Karakter, 0(1). https://doi.org/10.21831/jpk.v0i1.1307

[10] Yamin, M., \& Syahrir, S. (2020). Pembangunan Pendidikan Merdeka Belajar (Telaah Metode
Pembelajaran. Jurnal Ilmiah Mandala Education, 6(1). https://doi.org/10.36312/jime.v6i1.1121

[11] Zeraati, M., \& Alavi, N. M. (2014). Designing and Validity Evaluation of Quality of Nursing Care Scale in Intensive Care Units. Journal of Nursing Measurement, 22(3), 461-471. https://doi.org/10.1891/1061-3749.22.3.461

[12] Zulfa Izza, A., \& Susilawati, S. (2020). Studi Literatur: Problematika Evaluasi Pembelajaran Dalam Mencapai Tujuan Pendidikan Di Era Merdeka Belajar. In Konferensi Ilmiah Pendidikan 2020 (Vol. 1, Issue 1). https://proceeding.unikal.ac.id/index.php/kip doi: https://doi.org/10.24036/02013211268-0-00. 